\title{
Suppletion: questions for history and theory
}

DOI:

10.1111/1467-968X.12176

\section{Document Version}

Accepted author manuscript

Link to publication record in Manchester Research Explorer

\section{Citation for published version (APA):}

Plank, F., \& Vincent, N. (2019). Suppletion: questions for history and theory. Transactions of the Philological Society, 117(3), 319-337. https://doi.org/10.1111/1467-968X.12176

\section{Published in:}

Transactions of the Philological Society

\section{Citing this paper}

Please note that where the full-text provided on Manchester Research Explorer is the Author Accepted Manuscript or Proof version this may differ from the final Published version. If citing, it is advised that you check and use the publisher's definitive version.

\section{General rights}

Copyright and moral rights for the publications made accessible in the Research Explorer are retained by the authors and/or other copyright owners and it is a condition of accessing publications that users recognise and abide by the legal requirements associated with these rights.

\section{Takedown policy}

If you believe that this document breaches copyright please refer to the University of Manchester's Takedown Procedures [http://man.ac.uk/04Y6Bo] or contact uml.scholarlycommunications@manchester.ac.uk providing relevant details, so we can investigate your claim.

\section{OPEN ACCESS}




\title{
SUPPLETION: QUESTIONS FOR HISTORY AND THEORY
}

\author{
By Frans Plank AND Nigel Vincent
}

Somerville College, University of Oxford and The University of Manchester

\begin{abstract}
Introducing a collection of papers on suppletion looked at from a diachronic angle, this paper surveys questions that have been asked (or should be) and answers that have been considered, in this issue and elsewhere, about how, why, where, and when suppletion originates, with particular lexical items and morphological categories; what happens to suppletion once and as long as it is there; how, why, where, and when suppletion disappears again; and how suppletion fits with particular approaches to morphology and general theories of language.
\end{abstract}

\section{QUESTIONS FOR DIACHRONY}

Suppletion is not something dictated by the design of Language (capital $L$ ): stems (or roots or words, whatever the basic lexical units happen to be) that form the nuclei of the wordforms that comprise the inflectional paradigms of any or some lexemes, or the nuclei of any or some pairs of lexemes that serve as bases and derivatives in derivation, 
are not obliged to show suppletion. That is to say, none have got to alternate singularly, not following to the letter (well, sound) any formal pattern, phonological or morphonological, general or circumscribed, that is in evidence in the languages concerned. Nor are such unruly alternations precluded by the ways lexicons and grammars are authorised to operate by our brains and other speech organs and by the demands of communication. Neither prescribed nor proscribed, such unique alternations do occur: not in all languages (little $l$ 's) but in many; never affecting the inflection or derivation of all lexemes or lexeme-pairs but always of only a few, and each one differently as far as the alternations themselves go; and commonly with only selected inflectional or derivational categories, rather than all of them, occasioning radical deviations from the norm of lexical nuclei being invariant or only subject to rule-governed variation.

Producing the worst disturbances of morphological orderliness, the ultimate in allomorphy, such alternations, known as 'Suppletivwesen' since Osthoff (1899/1900), have long attracted attention. ${ }^{1}$ Lately, the crosslinguistic phenomenology of suppletion has come under considerably extended scrutiny. On an ever firmer factual footing, categorical or perhaps preferential constraints have been identified that appear to rein in

\footnotetext{
${ }^{1}$ Earlier, 'syncretism' had been the term applied to the same sort of (Un-)Wesen by de la Grasserie (1895). But what's in a name? When precise meanings were subsequently given to the term 'suppletion', they were not always in full agreement, either; Mel'čuk (1994) is often perceived as giving reliable orientation. Needless to add, the priority in our undertaking here is not precise defining as an end in itself, but posing and answering WH-questions about a reasonably natural domain that naturally has its fuzzy edges.
} 
even something as irregular as suppletion. In response, theoretical frameworks were devised or adapted so as to accommodate only such manifestations of suppletion as were being observed and not others conceivable but unattested.

Neither prescribed nor proscribed, hence outside the jurisdiction of existential universals, instances of suppletion therefore must be something that can appear, change, and disappear over time, perhaps that of the life spans of individual speakers, but certainly across generations within speech communities. With suppletion not affecting lexemes (inflection) or lexeme-pairs (derivation) ab ovo and ad infinitum, there must be some coming and going and some to and fro in between. However, notwithstanding an abundance of philological, language-particular case studies, the fathoming of the diachrony of suppletion, with an eye on explanation and understanding, has been lagging behind typological and synchronically-focused theoretical advances.

Shedding a little more light (i) on how, why, where, and when suppletion originates, with particular lexical items and morphological categories; (ii) on what happens or does not happen to suppletion once and as long as it is there; (iii) on how, why, where, and when suppletion disappears again, and (iv) how such patterns fit with particular approaches to morphology and general theories of language is the idea behind the present collection. ${ }^{2}$ We will use the opportunity of introducing it to highlight what we perceive as the major challenges and continuing controversies around the origin, progress, and loss of suppletion, at the same time commenting on the way the papers address these questions.

\footnotetext{
${ }^{2}$ On and off suppletion has inevitably come up in the Transactions of the Philological Society, often only touched on tangentially, though. A recent head-on article is Petré (2012), on the Old and Middle English copula.
} 


\section{LOSS}

If there is one morphological phenomenon that to all appearances cannot be made sense of without appealing to frequency, then it's suppletion. In terms of the life cycle of suppletion, frequency has been assumed to be implicated at both its beginning and end. Let's begin with the end, because here the role of frequency is clearest. Whether its explanatory potential extends back to its beginning is another question.

\subsection{Regularisation}

One robust diachronic insight, so ancient as best considered apocryphal, is simple and of such admirably sweeping scope as there are not (m)any others: suppletive lexemes of lower frequency of occurrence are more prone than higher-frequency lexemes to stop suppleting over time and turn morphologically (more) regular. ${ }^{3}$ There is no paradox here on the standard assumption that the most frequent words are the most irregular insofar as the reasoning invokes acquisition. Low-frequency lexemes give learners rarer opportunities of (i) even discovering that they are suppletive, and (ii) vigorously reaffirming such an irregularity should it accidentally have been picked up. Hence, by way of reasonable default, such lexemes will be taken to be regular: learners will retain only one lexical core form, the one actually encountered and remembered, which will

\footnotetext{
${ }^{3}$ Where convenient to supplete will also serve us as a verb. Attentive readers will notice that we are using 'suppletion' somewhat ambiguously as a mass and a count noun, the former continuing Osthoff's Suppletivwesen (1899/1900).
} 
serve for all of inflection and all of derivation when the lexeme is used again later. Irregular alternations of any kind and extent will challenge the learner's powers of memorisation and the chances are they may eventually be levelled out, too. But when suppletive lexemes/lexeme-pairs, supremely irregular, occur with high enough frequency, learners are at least getting a fair chance to prove their conformist mettle and rote-learn.

It remains to be seen whether the demise of suppletion can be quantified more precisely, along the lines of Lieberman et al. (2007) who suggest, as a bold law, that morphological regularisation rates are inversely proportional to the square root of usage frequency. Studying English irregular verbs over time, they found (or believe they found: as a contribution to English historical linguistics their study is seriously flawed) that an irregular verb that is a hundred times less frequent regularises ten times as fast. They did in fact include suppletive verbs among those 177 English verbs that were tracked over the past 1,200 years, along with strong verbs and others not forming their past tense "regularly" (essentially by suffix /Id, d, t/, with the verb stem unaltered). Being in the higher-frequency bins, where irregularity half-lives are reckoned (by extrapolation: English is not old enough for regularisations proceeding at the rate of the law to be observed) to range from 38,800 years (be, have) via 14,400 (do, go, say) to 5,400 years (stand), none of these suppletive verbs have in fact regularised. And no "irregular" verbs that were or were not regularised from the lower-frequency bins where half-lives range from 2,000 to 300 years were suppletive - which is an observation that frequency-controlled regularisation ratios as such fail to account for. Are English suppletive verbs so extraordinary, or is suppletion always only something for lexemes/lexeme-pairs that are so frequent as to be ever, within human dimensions, beyond rescue by regularisation? 
This puzzle could conceivably be accounted for if frequency also had its hand in the emergence of suppletion. But the question is: Does it? Does high-frequency contribute to lexemes/lexeme-pairs becoming suppletive in the first place? There appears to be no comparably compelling rationale to that of frequency-protected long half-lives of suppletion once it is there. That high-frequency words form 'weaker connections', something supposedly accounting among other things for suppletion (Bybee 2007: 171), does not self-evidently bear specifically on the origins of suppletion. Other rationales, at any rate, appear more compelling, and if frequency is implicated in these, too, it arguably is not itself the prime mover, prodding mental grammars to take this or that sort of action (see Section 3.3 below).

\subsection{Lexeme loss}

In the case of suppletion, regularisation involves discarding an irregular alternant; more drastically still, an irregular lexeme could simply be discontinued entirely. Suppose English decided to do without a copula in all circumstances, the most conspicuous instance of suppletion would disappear with the whole verb to be. Or suppose English were to limit copula use to the past tense, little would be left of this verb's suppletive alternations either. Such losses are conceivable with rarer and more culture-specific lexical items — such as, perhaps, nouns for 'corner of a bag', famously suppletive in the Daghestanian language, Archi (Kibrik 1977: 46, Corbett 2007: 34) — but they will never grow into an epidemic eliminating suppletion, which typically only affects core vocabulary.

\subsection{Phonological unification of separate lexemes}


Are there realistic ways for instances of lexemes/lexeme-pairs to cease to supplete other than through regularisation? If there are, they are not especially conspicuous. What is more commonly emphasised rather is that, like cats, suppletions have many lives, with new suppletive stems stepping in when old ones are retired, forgoing chances to regularise at such junctures. A typical story here tells of English resorting as the past tense of go to suppletive went, itself the past of the semantically related verb, to wend rather than opting for regularisation (*go-ed) when an opportunity arose, insofar as the erstwhile suppletive past tense form of gān 'to go', Old English eo-de, a regular past form of a different verb that was itself defective, lacking a present, fell into disuse (except in dialects retaining forms such as yode). Meanwhile, wend continues in a marginal usage — in the fixed expression wend one's way — with the fully regular past, wend-ed in contrast to other verbs of this shape which commonly form their past in the manner of went: send, sent; bend, bent; spend, spent; lend, lent; rend, rent; build, built; earlier also blend, blent; gild, gilt and others (see Kayne, this vol, for a new interpretation of these facts). This latter development is moreover a nice instance of lowered frequency concomitant with a loss of irregularity.

But there are instances, perhaps rare, where suppletion is undone, and not through morphological regularisation, but through phonological unification of separate lexemes - in a sort of reverse development to one of those creating suppletion. ${ }^{4}$ For example, in Old Irish, the high-frequency noun for 'human being' was suppletive, with

\footnotetext{
${ }^{4}$ The championing by Werner (1977) of the phonological grounding of suppletive developments is a rare acknowledgment of such a possibility. The Irish case is taken from Meid (1976) via Werner.
} 
singular stem duine /'dun'e/, from the io-declension, and plural doini /'doin'i/, from the i-declension, etymologically different: the singular, drawing on the conceptual opposition to 'heaven', abode of the gods, is literally 'earthling', based on the Celtic and Indo-European root for 'earth' (* $(g)$ doniio- $<*$ g'hdhom-yo-), while the plural is based on deverbal *dhouen-eies 'those fading away, vanishing; mortals'. Though distinct, the two lexemes sharing in the number inflection of 'human being' were phonologically not dissimilar, and over time they became so similar as a consequence of vowel changes that they could be considered regular singular and plural of one 4th declension stem:

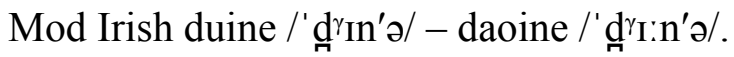

\section{ORIGINS}

Unruly alternations are not a homogeneous phenomenon regarding their origins, although the term 'suppletion' has sometimes been reserved for just one such origin: lexeme combination as opposed to phonological differentiation. A strong argument against such a restrictive terminological policy is that synchronically suppletions do not wear their origins on their sleeve. For example, Liverpudl-ian and Salop-ian designate persons from Liverpool and Shrewsbury in England, but how have they come to be suppletive? If anything the phonological distance from the place name is wider with the second demonymic derivative: but this is not a reliable pointer to modes of origin, and in any case will not matter for learners acquiring a mental lexicon and morpho-lexical relations. But there remain questions of substance rather than terminology about the different paths to suppletion and about when and why one or the other would be taken.

\subsection{Dual route: Phonological differentiation and lexeme combination}


Form alternations in inflection and derivation that do not follow language-particular rules can come about in two ways: (i) through developments affecting the form alternations, away from a state where they were following live (morpho-) phonological rules to one where they don't any longer, with phonological changes or analogy having severed the links between the alternants; ${ }^{5}$ and (ii) from the convergence and coalescence of complementary subsets of wordforms originally belonging to separate lexemes into one lexeme in inflection, or of separate lexemes in one basis-derivative pairing in derivation where other such pairings keep the basis as part of the derivative. ${ }^{6}$ Thus, the paths leading to suppletion that need to be distinguished are (i) phonological differentiation and (ii) lexeme combination, with possibly further refinements and variations of these two basic themes.

Complementing the footnote examples on this page from derivation and thereby suggesting that suppletion springs up equally in these two morphological compartments, ${ }^{5}$ Shrewsbury $\rightarrow$ Salop-ian (with Salopian also serving as a demonym for people from the entire county of Shropshire): the first element in OE Scrobbes-burh/-byrig 'fortified place in (a district called) the Scrub' developed to Scirop-(scire) (whence Shrop-shire) through vowel epenthesis, but was alternatively changed to Salopes-(berie) by Norman or Anglo-Norman speakers equally adverse to onset clusters and replacing /r/ by /1/ (whence Salop-ian), while the most regular native continuation of the old name was to lead to the town name's modern version, Schrobes-berie $>$ Shrows-bury $>$ Shrews-bury. ${ }^{6}$ Liverpool $\rightarrow$ Liverpudl-ian: the second part of the compound place name, from $\mathrm{OE}$ lifer-pōl 'pool with muddy water', was playfully-derogatively replaced by a stem of similar form and meaning, puddle. 
both processes can be seen at work in inflection in the case of the Latin verb ferre 'bear', where the imperfective forms are built to the stem fer-(fero, ferebam, ferens, etc.) while the perfect forms are built to the stem tul-(tuli, tuleram, tulissem, etc.), and the past and future participles to the stem lat-. The latter two are connected via sound change since lat-involves the attachment of the participial suffixes -atus and-aturus to the zero grade of the stem telh $_{2-}$ 'support, weigh' with subsequent reduction of the initial cluster [tl]. By contrast, fer- is the reflex of a lexically distinct stem *bher- 'bear, carry'. What this example also demonstrates is how much our understanding of particular developments relies on the rich historical evidence and detailed reconstructive work by several generations of scholars that is par for the course in Indo-European studies but is simply not available for many other languages and language families. Even so, questions remain. Why did these lexemes converge to form a single paradigm in Latin but not in other members of the family? What exactly was the semantic relation between them at the point where the suppletive pattern begins to emerge? What types of sound change are sufficient to induce in speakers and learners a sense of formal unrelatedness as opposed to mere phonological irregularity?

Beside these two routes, phonological differentiation and lexeme combination, Hill (2015 and this issue) suggests a third possibility, namely, a shift from a derivational to an inflectional relation between forms. Thus, forms like the above-mentioned latus in Latin are traditionally labelled past participles but they are in origin a class of deverbal adjectives (Joffre 1986) which over time have become integrated into the verbal paradigm via the contrast between active and passive pairs such as fecit ' $(\mathrm{s})$ he did' and factum est 'it was done'. One verb that in Latin did not have - and did not need - a past participle for these purposes was esse 'be'. However, with the grammaticalisation of the passive periphrasis that takes place in the transition from 
Latin to Romance, 'be' also requires a past participle in strings such as French $l a$ question a été posée 'the question has been put', and for this purpose takes over the past particple of stare 'stand', whence French été in this example and its Italian cognate stato. Spanish and Portuguese, on the other hand, have recourse to sedere 'sit' for their past participle sido, as discussed by Juge in this issue.

An argument of this kind in turn assumes that suppletion is only possible when the relation between the forms falls within the bounds of inflection, itself by no means a boundary that scholars are agreed on. A case in point, other than our footnote examples of English demonyms, concerns comparatives and superlatives such as English good, better, best or Latin bonus, melior, optimus, patterns which are standardly treated as suppletive already in Osthoff (1899) and in more recent discussion informed by modern theoretical developments (Bobaljik 2012, Plank 2016b). Assuming that these patterns are indeed suppletive in the sense of Mel'čuk (1994) as involving maximal formal irregularity combined with maximal semantic regularity, it follows either that suppletion extends beyond the boundary of inflection as strictly defined or that comparative and superlative formation is indeed a kind of inflection. But perhaps a better conclusion, itself implicit in Mel'čuk's definition, is that all analytical boundaries of this kind are fuzzy. This in turn is consistent with the inevitably gradual nature of the mechanisms of linguistic change and makes diachronic questions such as those raised - and in part answered - by our contributors central to our understanding of the phenomenon.

One consequence of the different diachronic routes to suppletion is whether or not the outcomes display systematicity in terms of their synchronic patterning. The net results are indistinguishable as far as the formal relationships between alternants are concerned: as long as they are not rule-governed, or else we would not be dealing with suppletion in the first place, the alternants can be phonologically more or less dissimilar 
from one another whatever their history. There is a question, however, in particular in inflection, whether suppletion resulting from phonological differentiation and lexeme combination can differ in the way the alternants are distributed over morphological systems. It has been suggested that when distinct stems (or roots or words) come to be yoked together to share in the labour of expressing inflectional contrasts, such combinatory suppletion will tend to respect paradigmatic structures: suppletive stems will do duty for subsets of categories which can be grouped together as natural classes within their paradigmatic system (definable through feature structures or paradigm geometry à la Jakobson or Hjelmslev). For example, when two stems are combined for purposes of number and case inflection of a noun, one is likely to take care of all cases of one number (or subset of numbers) and the other of all cases (or subset of cases) of the other number(s). Or, possibly because dominance relations among these categories can differ across languages, they will be distributed by case, with one stem taking care of all numbers of one case (or subset of cases, such as all direct or all oblique ones) and the other of all numbers of the other (subsets of) cases. Sometimes distributions will be more complex, in terms of feature combinations or geometric arrangement, but arguably they will not be morphologically random - such as dividing up a case and number paradigm into, say, an ACC.SG, DAT.SG, NOM.DU, GEN.DU, ABL.PL subset/subarea for one alternant and a NOM.SG, GEN.SG, ABL.SG, ACC.DU, DAT.DU, ABL.DU, NOM.PL, ACC.PL, GEN.PL, DAT.PL subset/subarea for another alternant. (Assuming nothing in the language concerned will define precisely these sets/areas as complementary natural classes.) On the other hand, when phonological differentiation is the mechanism leading to suppletion, paradigmatic structures will not as such rein in the resultant patterns, except perhaps coincidentally, if reflected in phonological patterns. 
This sort of reasoning would not lead us to expect to find universal timeless constraints on paradigmatic distributions valid for any and all instances of suppletion: such constraints would be expected to be diachronic, only applying when lexeme combination is the relevant step in creating suppletion to curb the mergers of subsets of wordforms of historically distinct lexemes. An example Plank (2016a) discusses is a paradigmatic cross-over constraint on suppletion - say, prohibiting verbal suppletion with 1SG and 3PL sharing one stem and 2SG, 3SG, 1PL, 2PL sharing another, given standard paradigm structures for person and number - which is found to be violated only in suppletions whose origin is phonological differentiation.

A complicating factor here is the role of the morphome, that is to say a set of forms that may have originated as a result of sound change, but which have subsequently come to act as the conditioning factor for later developments including suppletion (Maiden 2004, 2018). Thus, the Savognin verb dueir 'must' (< Latin debere) has the forms as set out in the following table (Table 6.54 from Maiden 2018):

\begin{tabular}{|c|c|c|c|c|c|c|}
\hline & $1 \mathrm{SG}$ & $2 \mathrm{SG}$ & $3 \mathrm{SG}$ & $1 \mathrm{PL}$ & $2 \mathrm{PL}$ & 3PL \\
\hline PRS. IND & stó & stóst & stó & duágn & duéz & stón \\
\hline PRS. SBJV & stóptga & stóptgas & stóptga & stóptgan & stóptgas & stóptgan \\
\hline IPF & duéva & duévas & duéva & duévan & duévas & duévan \\
\hline COND & duéss & duéssas & duéssa & duéssan & duéssas & duéssan \\
\hline
\end{tabular}

The pattern to be seen in the present indicative, where the forms of the almost synonymous stueir have taken over all the cells except the first and second singular of the indicative, instantiates the morphome labelled the N-pattern by Maiden. Indeed Maiden (2018: §11.1) goes so far as to assert: 'It is not just that lexical suppletion may 
assume morphomic patterns of distribution in Romance: apparently it must.' The consequences of this approach are explored here in Kim's contribution, while in his paper Juge expresses some reservations about Maiden's general conclusions.

\subsection{Defectivwesen}

But why would distinct lexemes ever merge into one in the first place? Defective paradigms have sometimes been invoked as important catalysts of combinatory suppletion, and the resulting suppletive distributions would then be expected to be as orderly or random as the original gaps were. Now, paradigms can be defective because of phonotactic conflicts arising in combinations of morphological material are unresolvable or because of other phonological inadequacies (such as insufficient prosodic weight of inflected or derived words), and it would then be a coincidence if they followed morphological patterns. Or particular morphological categories (often paradigmatically exposed ones such as participles in verb inflection) of particular lexemes can be affected for no apparent reasons at all. But the reasons for gaps can also be transparently semantic, as with pluralia/singularia tantum nouns or 3rd-person-only impersonal verbs (see Baerman, Corbett \& Brown 2010 for a recent overview). And once again the morphome concept, if independently justified, complicates the picture, as in the discussion of some Romance developments in Maiden (2018: §6.2.4).

However, in many instances where the gestation and birth of an instance of suppletion can be traced, no initial gap can be found which another lexeme would have been called upon to fill. Rather, the complementary distribution of suppletive stems over the paradigm, through dropping one stem where the other was retained and vice versa, was only negotiated subsequently. Hence Osthoff's term 'Ergänzungswesen', 
perceiving complementariness as the most conspicuous peculiarity of such developments, vis-à-vis 'Defectivwesen' as earlier suggested by Gabelentz (1891) for what eventually became known as suppletion.

Ascertaining the role of paradigm gaps as invitations for suppletion and pursuing the original shaping and/or subsequent re-shaping of complementary distributions of suppletive alternants, avoiding doubly filled cells in unified paradigms, seem to us to remain major issues. Also, if Janda \& Tyers (2019) are right, defectivity is not necessarily a bad thing, and therefore may not always need to be remedied.

\subsection{Salience: Frequency or meaning?}

As we have seen, frequency as such is unlikely to spawn suppletion; instead the best predictor here seems to be meaning: being in common everyday use and designating something that is perceptually, cognitively, or culturally salient will increase the chances (or threat) of lexemes to be harnessed together in order to express certain paradigmatic contrasts. Moreover, it is precisely these lexemes which are least likely to be handicapped by random paradigmatic gaps, a fact which also argues against the thesis of defectivity as the driving factor.

But why is it in this sector of the vocabulary that suppletion appears to be thriving? Arguably, responsibility lies not with frequency as such, but it is a psychological quality, salience, that has been seen as encouraging a particular mode of designation. Osthoff's reasoning was as follows - and more recently Wurzel (1985, 1987) and Bittner (1988) have followed closest in the suppletion pioneer's explanatory footsteps: 
Wir können bei etwas genauerem zusehen nicht verkennen, dass es lauter dem seelischen interesse des sprechenden menschen näher liegende vorstellungsobjekte sind, deren sprachliche bezeichnungen als im banne der suppletivischen ausdrucks- und formenbildungsweise stehend sich erweisen. [...] die lösung unseres problems von der psychologischen seite her wird nun darin zu erblicken sein, dass ein bekannter erfahrungssatz auch hier seine geltung findet: wie der mensch mit seinem leiblichen auge allemal das räumlich zunächstliegende in schärferer besonderung erschaut, so werden auch mit dem seelischen auge, dessen spiegel die sprache ist, die dinge der vorstellungswelt desto schärfer und individueller erfasst, je näher sie dem empfinden und denken des sprechenden treten, je intensiver und lebhafter sie in folge dessen das gemüt zu ergreifen, das psychische interesse des einzelnen, $d$. i. des menschen- und des völkerindividuums, zu erregen pflegen. Es arbeiten sich auf dem gebiete der wortschöpfung und formenbildung von anfang an zwei tendenzen entgegen. Einerseits ist der sprachsinn frühzeitig und beim altern der sprachen in immer zunehmendem masse auf gruppierende dingauffassung gerichtet. [...] Diese richtung liegt aber von jeher, und zwar im allgemeinen siegreich fortschreitend, zu felde gegen den trieb der individualisierenden dingauffassung. (1899: 41-43, passim)

Thus, German Sohn and Tochter (like English son and daughter) instantiate the 'individuating' mode of designation, while its Latin counterparts are 'grouping' (or 'relating'), with the sense shared by these two kin terms expressed through employing 
the same stem, fil-ius and fil-ia; parallel male-female semantic pairs in German (and partly English) are grouping, too, which (for some. though not all morphologists) warrants seeing pairs such as Sohn and Tochter as suppletive in the first place (EnkelEnkel-in 'grandson - granddaughter', Schwager - Schwäger-in 'brother-in-law - sisterin-law', Pate - Pat-in 'godfather - godmother', Gastgeber - Gastgeber-in 'host - hostess', Löwe - Löw-in 'lion - lion-ess', etc.). Analogously for the terms of inflectional systems, where German is grouping in the singular-plural pair Mensch and Mensch-en, while Russian is individuating with its čelovek and ljud-i (and English man and men is in between). Although Osthoff holds back with judgments about intellectual progress, he nonetheless sees morphological development as unidirectionally moving from individuation to grouping, from suppletion to compositionality. ${ }^{7}$

Actually, such new designations do not really need to be coined anew because this part of the lexicon covering what Wurzel called 'Nahbereich' after Osthoff is to be expected to be teeming with (near-)synonyms anyhow:

Wenn es in der sprachlichen formenbildung sich bekundet, dass des menschen gemüt, seele und geist das lebhaftest interessierende am individuellsten erfasst [...], so lässt sich in verbindung damit erwarten, dass für manche der begriffe, die am suppletivwesen beteiligt sind, ganz üblicher weise eine grössere fülle sinnverwandter wörter, sogenannter synonyma, ausgeprägt und in umlauf zu sein pflegt. (Osthoff 1899: 46)

\footnotetext{
${ }^{7} \mathrm{He}$ also see the individuating mode of designation as the more poetic, and allows for occasional reassertions of the poetic over the prosaic principle in evolution.
} 
Hence, all it needs is to select among existing (near-)synonymous lexemes and yoke them together in single suppletively-inflecting lexemes or suppletively-deriving lexemepairs. Now, if the existence of (near-)synonyms is recognised as a prerequisite for suppletion, this raises the question whether that part of the argument which invokes individuating vs. grouping modes of designation, given such prominence by Osthoff and Wurzel and Bittner, is really a necessary component for an account of its origin - except indirectly, in order in turn to explain unequal synonym distributions over the lexicon. It may suffice to state in an explanatory account of suppletion as such that without central lexical fields densely populated with synonyms and near-synonyms, lending themselves to distinguishing the finest semantic nuances if needed or desired, a pool of potential inputs into new suppletive partnerships would simply be missing.

Elaborating on this theme, the relation between lexemes that can be expected to come together in a particular case of suppletion appears to involve more than (near)synonymy, but neither is it hyponymy the right relation. Börjars \& Vincent (2011) suggest instead that in any given suppletive pair one item must be dominant and the other recessive. In other words, one item has a broader semantic range than the other, but still does not encompass all the meanings associated with the latter. Thus, in the English go/went case, go in origin means 'walk' (as still in modern Danish gå), but also has a number of directional uses, while wend specifically means 'turn' without necessarily implying any means of locomotion. These and other issues concerned with the semantic relations between inputs to a suppletive verbal paradigm, and in particular the role of semantic maps as a way of modelling such relations, are the specific focus of Juge's contribution to this collection. By contrast, in her paper Julia introduces a pragmatic dimension to the question through her exploration of the role of speaker choice as it relates to the formation of suppletive patterns. 
A different take on verbal semantics emerges in François's investigation of the phenomenon of verbal number as exemplified in the alternation between $t \bar{o}$ ' $\mathrm{go,SING}$ ' and vën 'go.PLUR' in the Oceanic language Hiw, leading to the conclusion (similar to that of Mithun 1988) that beside intra-paradigmatic alternations of the kind that the label suppletion traditionally refers to we need to recognise groupings of related items within the lexicon, or what he calls 'lexical paradigms'. It is interesting too that the lexical classes he identifies are similar to but yet distinct from the classes that are regularly involved in suppletion. Whereas the latter are typically claimed to involve items with general meanings such as 'do' and 'be', lexical paradigms appear to form around words with concrete meaning like 'fall', 'sleep', and 'jump'. There may be items that fall into both classes, such as 'go' and 'come', but nonetheless they are distinct.

Alternatively, one may seek to remove the question from the domain of semantics altogether, and see the special behaviour of words like English go or French aller as due to the fact that they belong to a different syntactic category, namely so-called 'light' verbs, as proposed here by Kayne in his contribution. ${ }^{8}$

\subsection{The threshold}

\footnotetext{
${ }^{8}$ Despite some considerable overlap in class membership, Kayne's 'light verbs' are not to be confused with the 'light verbs' of minimal semantic content forming complex predicates with more contentful words (usually nouns), which tend to be inflectionally inert, synchronically and diachronically (Butt \& Lahiri 2013).
} 
Whether suppletion arises through phonological differentiation or the combination of (near-)synonymous lexemes, there is still the question of the threshold to that new state of things, suppletion. Though potentially subtle, determining when regular alternants of a single lexeme have ceased to be relatable by (mor)phonological rule is the easier decision in principle. Deciding precisely when two lexemes co-existing as synonyms have coalesced in one lexeme is the harder nut. Other than near-synonymy having turned into semantic identity, what is crucially required for the threshold of suppletion to be crossed, presumably, is complementariness in the division of morphological labour rather than duplication. Complementaries can't contrast. For example, Leut-e 'people-PL' in Standard German is a plurale tantum and can therefore be considered to be especially close to Mensch 'person, human being'; ${ }^{9}$ however, other than supplying singular forms that Leut-e is missing, Mensch itself has all plural forms, thereby duplicating the inflectional contribution of Leut-e. Differing from Mensch, plurals are what Russian čelovek is missing, thereby neatly complementing the plurale tantum ljud-i in doing their full inflectional duty. On the other hand, we have already cited the case of the Italian form stato, which serves both as the regular participle of the verb stare 'stand' (compare dare/dato 'give/given) and as the suppletive participle of essere 'be'. In the same vein, Juge in his paper considers the Spanish forms fui, fuiste, etc, which serve as the preterit of ir 'go' and ser 'be' and are suppletive in both cases (and compare the discussion by Maiden (2018: §6.2.4) of the overlap in function of forms of the Savognin verb stueir 'must, be obliged').

\footnotetext{
${ }^{9}$ Actually, the semantically closer singular correspondents of Leut-e are Mann 'man' and Frau 'woman', complicating the network of potential suppletive partnerships. Collective and generic senses are subtly subverting full synonymy.
} 
Accounting for how suppletive-partners-to-be go about negotiating their economical collaborations remains a major challenge of suppletion studies. Paradigmatic systems in derivation tend to be simpler, hence achieving the perfect interlocking that completes the parturition and marks the birth of suppletion will be a more complex effort in inflection. Instances of suppletion coming about in this way have not been observed often in statu nascendi, especially when this has occurred in some distant past documented only fragmentarily. There is a data problem here, as Hill laments in his contribution.

Amalgamating one lexeme with a (near-)synonymous dominant/recessive other so as to become one will not normally be a conscious intentional process, with speakers deliberately aiming at certain patterns and avoiding others, especially in inflection when the categories involved are relatively abstract. Rarely it probably is: Wurzel (1985: 141) mentions expressive elatives of German adjectives groß 'big' and gut 'good' such as riesig 'gigantic' and klasse 'classy'; ${ }^{10}$ playfulness was involved when Liverpoolers were made fun of as Liverpudlians or Scousers (lobscouse eaters).

\subsection{Phonological similarity?}

${ }^{10}$ It is dubious, though, whether German in fact has such a category of comparison, in addition to a positive, comparative, and superlative. Perhaps periphrastic am größten/besten, mysteriously combining the synthetic superlative with inseparably fused local preposition and definite article, an dem >am, can be said to have elative function, and the intensifying adjectives that Wurzel mentions are near-synonyms, at best incipiently suppletive. 
While semantic similarity of lexemes is clearly a prerequisite, phonological similarity has also been suggested to be conducive to combinatory suppletion (for example by Werner 1977). If valid, this would favour shorter over longer lexemes, because the more phonological material, the unlikelier lexemes will be sound-alikes. And according to Zipf's Law, the more frequent the shorter. However, the evidence for generalising here seems to us spurious: overall, suggestive instances - such as Archi bičnni-boždo, suppletive singular and plural of the noun 'corner of a sack', sharing a few segments, quite a few features, and the phonotactic template CVC.CV despite originating from distinct lexemes; the German suppletive verb geh--ging-/gang- 'go' (see below, Section 4), going back to distinct, but phonologically none-too-dissimilar nearsynonymous Germanic lexemes *gai- and *gang-; or overlaps in usage and suppletive intermixtures of the near-synonymous distinct verbs statuere and sistere in Latin, 'to cause to stand, put, place', with phonologically rather similar perfects statū and stetī (Willi 2016) - must be a small minority. We therefore continue not to see a direct role for frequency in the genesis of suppletion, as opposed to its retention.

\section{PROGRESS}

From a diachronic perspective suppletion looks to be a random process insofar as even partly cognate and semantically overlapping items in closely related languages do not necessarily show parallel developments: compare English BE (am, are, is, was, were, been) with Danish VÆRE (er, var, varet), or Italian ANDARE (vado, andiamo, andai, andato) with Spanish IR (voy, vamos, fui, ido). The question then is: How are suppletive stems distributed or redistributed over inflectional paradigms? 
As argued earlier, at the point of origin suppletive forms can be distributed randomly (morphologically speaking) if suppletion is due to phonological differentiation of single stems. By contrast, if suppletion comes about through the combination of distinct stems into a single lexeme, the distributions can be expected to follow morphological lines and to respect categorial hierarchies. Yet again, if suppletion is a response to defective paradigms, then distributions might also be random, given that the original paradigmatic gaps may well have been themselves the outcome of unresolvable phonological conflicts.

Now, what happens to suppletion once and as long as it is there, with its manner of origin unfathomable for speakers? Is it stable or unstable? Are its patterns invariant or changeable?

Initial paradigmatic distributions are often remarkably stable, give or take minor extensions and withdrawals especially in peripheral paradigmatic locations. Even when one of the suppletive stems is subsequently replaced by another (as in the cases of Swedish and Norwegian bra for god 'good' or English went for eode 'go', paradigmatic patterns usually remain essentially unaltered.

But again, sometimes redistributions are rampant. One might expect them in particular when initial distributions were morphologically random because phonology had done the ordering. Or they might be concomitants of a return to morphological regularity by levelling out a suppletive lexeme's paradigm, with some degree of interim randomness in the step-by-step advance of the winning stem over the paradigm. In either case, the morphological system of the language concerned would be expected to curb the possibilities for restructuring.

But suppletive stems are also redistributed elsewhere, and with little apparent constraint. The verbs of autolocomotion and posture, gehen 'go, walk' and stehen 
'stand', in German and its dialects are a case in point; examples are given here only for the former. ${ }^{11}$ The contemporary Standard German picture of how the paradigm is partitioned by the stems geh- and ging-/gang-could not be neater:

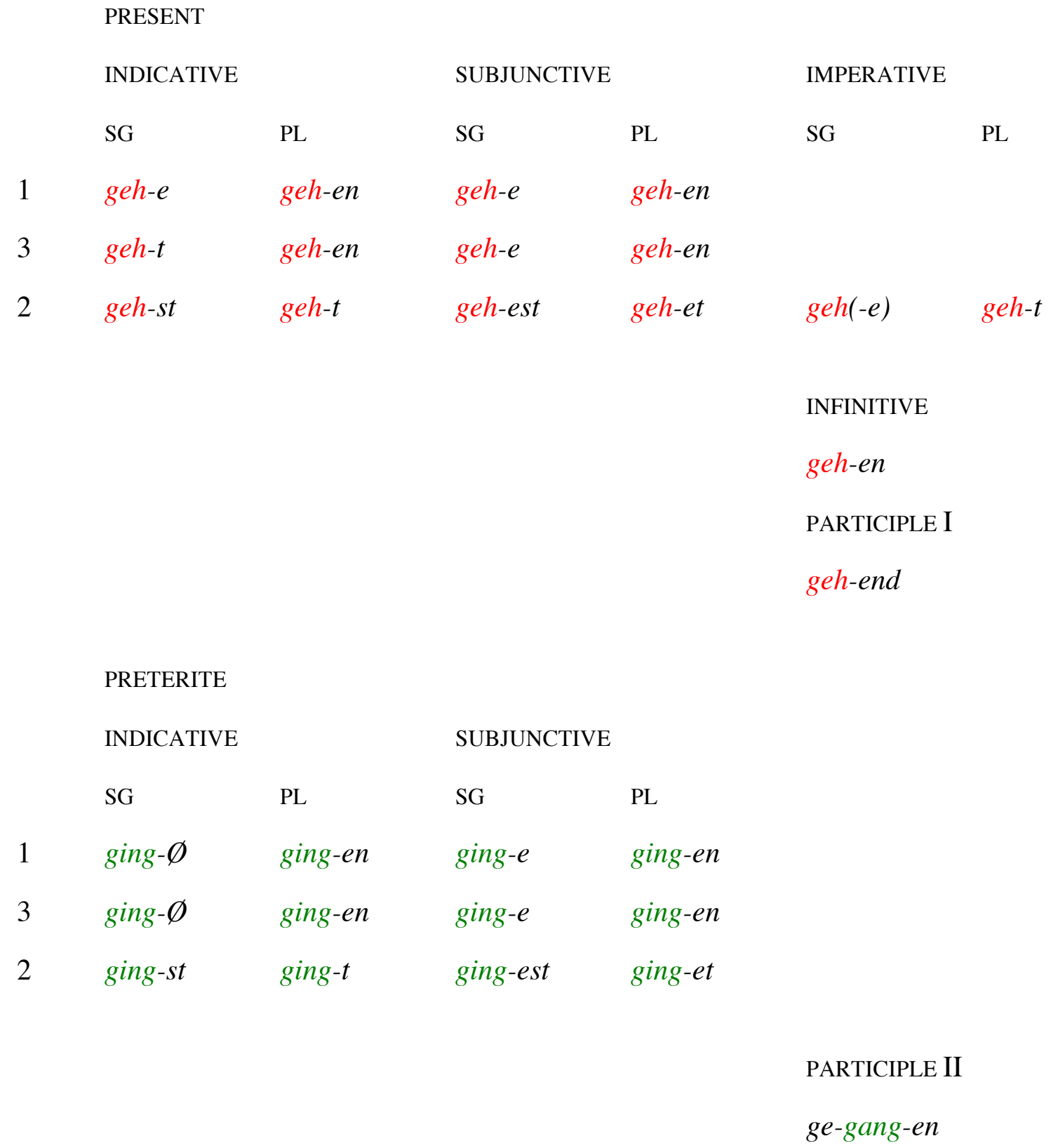

${ }^{11}$ Here summarised from Plank (2013), omitting much detail and context. 
To give some historical background, geh- and gVng-are historically distinct lexemes, the first one of the irregular Germanic short verbs, whose old hallmarks were a monosyllabic infinitive and a 1SG.IND.PRES in $-n$, the latter a strong verb of ablaut class VII. The suppletive stems are straightforwardly distributed by Tense (as elsewhere in Germanic, such as Danish/Norwegian/Swedish gå- and gikk- and English go- and wend, and unlike the suppletive stems all-, $v a-, i-$ 'go' in French etc., which show more complex distributions defined through more than one inflectional category). This distribution of geh- and gVng- essentially continues that of Middle High German, except that $g V n g$ - used to be an option for 2SG.IMP (MHG ganc/genc/ginc alongside $g \hat{a} / g \hat{e})$, and that $g e h$ - used to be an option for Participle II (ge-gâ-n alongside (ge-)gangen) and for $1 \& 3$ SG.IND.PRET (gie- $\varnothing$ alongside gienc- $\varnothing$ ).

Dialects of German - and we are singling out varieties of Bavarian and Alemannic, both Upper High German - have been redistributing the suppletive stems wildly (synthetic indicative preterites and present participles are uncommon or nonexistent in these dialects; persons are arranged 1-3-2 for good reasons; subject personal pronouns are added for local colour):

Middle Bavarian

PRESENT

INDICATIVE

SG

$1 \quad i: g \varepsilon: \varnothing$

$3 \quad \varepsilon \boldsymbol{\varepsilon} / \mathrm{si}: \mathrm{g \varepsilon}:-d$

$2 \quad d u: g \varepsilon:-s d$
PL

mie 'gey-en(d)

de: 'geり-en(d)

ie/e:s ge-ts
SUBJUNCTIVE

SG

$$
\text { 'ge:-ed-Ø }
$$

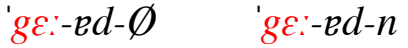

'ge:-ed-sd 'ge:-ed-ts
IMPERATIVE

SG PL

$g \varepsilon:-\varnothing \quad g \varepsilon-t s$ 
'ge:(-e)

PARTICIPLE I

'ge:-ed

PRETERITE

\begin{tabular}{|c|c|c|}
\hline & \multicolumn{2}{|l|}{ SUBJUNCTIVE } \\
\hline & SG & PL \\
\hline 1 & $\operatorname{ga\eta }(-e d)-\varnothing$ & 'gay-ed-n \\
\hline 3 & 'gay $(-e d)-\varnothing$ & 'gay-ed-n \\
\hline 2 & 'gay $(-e d)-s d$ & 'gay-ed-ts \\
\hline
\end{tabular}

PARTICIPLE II

'gay-e

Bodensee Alemannic

PRESENT

INDICATIVE

SUBJUNCTIVE

IMPERATIVE

SG

PL

SG

PL

SG

PL

$1 \quad$ ig $\tilde{a}:-\varnothing$

mie 'gay-'t

'gã :- $t$

'gã :- $t$

$3 \quad \varepsilon \varepsilon / s i g \tilde{a}:-t$

si 'gay-'t

'gã:-'t

'gã:- 't

2 du: gã :-S iv 'gay-'t

'gã:- 's

'gã:- 't

gã:- Ø 'gay-'t

INFINITIVE

$g \tilde{a}:$

PRETERITE

SUBJUNCTIVE

SG

PL 
3

2

Varieties of Low and High Alemannic

PRESENT

INDICATIVE

SG

PL

mis $g O n-d$

$3 \quad \varepsilon \mathcal{E} /$ si $g O:-t$

si gOn-d

$2 d u g O:-S$

ie $g O n-d$

\begin{tabular}{|c|c|}
\hline 'giəท $(-' t)$ & 'giวy-'t \\
\hline $\operatorname{giag}\left(-{ }^{\prime} t\right)$ & 'giə̀- - 't \\
\hline 'gian-'S & 'giəク- \\
\hline
\end{tabular}

PARTICIPLE II

'gay-'
SUBJUNCTIVE IMPERATIVE

SG

PL

$g O:-' t$

$g O:-' t$

$g O:-' t$

gO:-'S

$g O:-t^{\prime}$

gOÜ-Ø/gay-ØgOn-d

$g O \ddot{U}$

PL

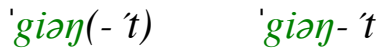

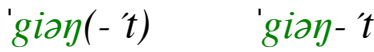

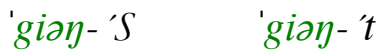

PARTICIPLE II

'gay-' 
Swabian and Eastern Bodensee Alemannic

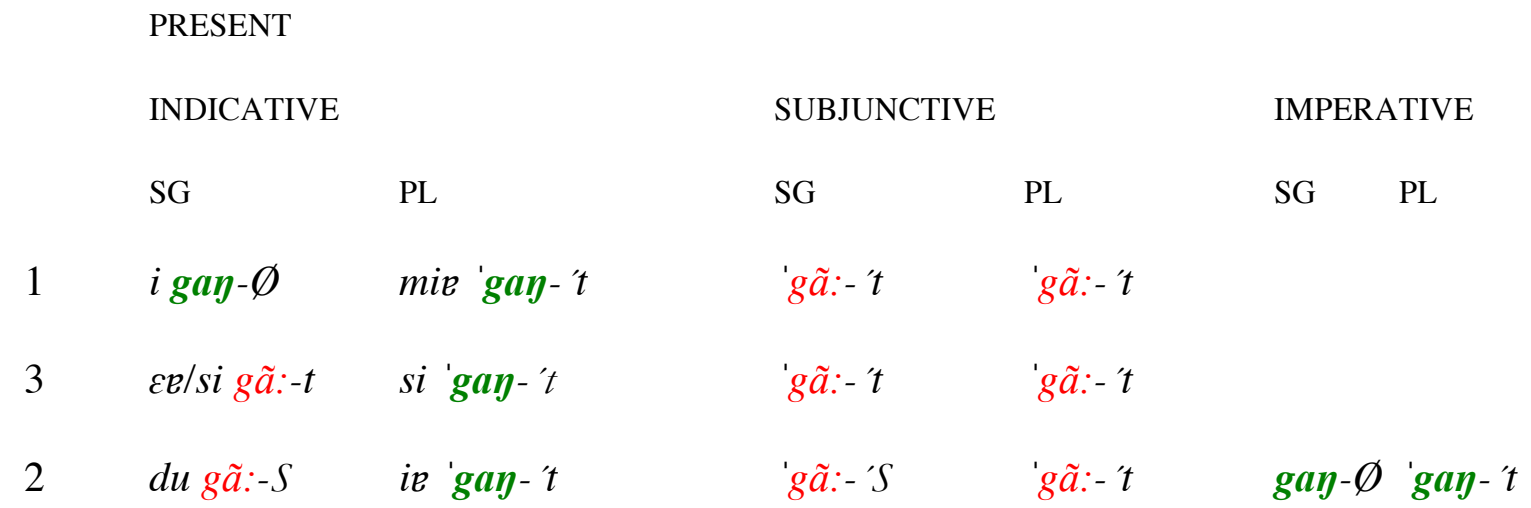

PRETERITE

\begin{tabular}{|c|c|c|}
\hline & \multicolumn{2}{|c|}{ SUBJUNCTIVE } \\
\hline & SG & PL \\
\hline 1 & 'giəø(-'t) & 'giə⿹-'t \\
\hline 3 & 'giəђ $(-' t)$ & 'giay-'t \\
\hline 2 & 'giay- 's & 'già- 't \\
\hline
\end{tabular}

PARTICIPLE II

'gay-'

We recognise five main themes running through these variations. The preterite suppletive stem can be extended, at the expense of the present stem, beyond its erstwhile Tense domain to $1 \& 3 \mathrm{PL} . \mathrm{IND}$, and also to $2 \mathrm{PL}$ when person distinctions are wholly neutralised in the Plural (a trait Alemannic shares with English); (ii) to 1SG.IND; (iii) combining the two patterns, to $1 \& 3$ PL.IND (or all plural persons when neutralised) and also to $1 \mathrm{SG} . \mathrm{IND}$; (iv) to 2SG.IMP (and automatically also to 2PL.IMP if extended to 
2PL.IND, too, with 2PL.IMP never distinct from 2PL.IND); (v) to non-Finite forms, most commonly in conjunction with extensions to IND and IMP sections. There are some general paradigm structure constraints that are being observed, ${ }^{12}$ but otherwise these redistributions seem pretty uninhibited, freely crossing even the present/preterite Tense divide, so conspicuous with all kinds of paradigmatic patterns for all kinds of verbs in Germanic and beyond.

If these spirited developments (and the Romance counterparts as set out in the present collection by Remberger \& Pomino are no less lively) are compared, for example, with the copula across German(ic), where original distributions of the ancestral three or four distinct stems, plus some more owing to phonological differentiation, have been maintained for ages more or less faithfully, ${ }^{13}$ the question arises: Why are there such differences in distributional stability? The answers are pending. This isn't one - but it seems that sometimes, as with German gehen, suppletive lexical items are fully integrated, with their inflectional paradigms not strictly subsectioned, whereas sometimes, as with the German(ic) copula, the stems that have come to be joined in one lexeme continue to delimit autonomous subsections of the paradigm from which it is hard for a stem to escape. Relevant here too is the morphome as a concept which defines classes of forms united only by their morphological effects rather than by any phonological or morphosyntactic properties (Maiden 2018).

\footnotetext{
${ }^{12}$ And there are many more redistribution that would have been in line with such constraints, too - except they do not appear to have happened anywhere.

${ }^{13}$ Non-finite or less finite (such as imperative) sections of verbal paradigms seem the likeliest locus for redistributions.
} 


\section{ENCOURAGEMENT AND DISCOURAGEMENT FOR SUPPLETION}

So far we have been asking which lexical items, from which areas of the lexicon, can be expected to become and remain involved in suppletion, separately looking at the different stages in the life-cycle of suppletion. But when lexemes are among those that may become and remain so afflicted, there is also the question of factors encouraging or discouraging suppletion and shaping its patterns: not all (near-)synonyms for cognitively salient, Nahbereich concepts will be equally suppletive in all languages and in all morphological circumstances. In terms of life-cycles, it would seem that any such encouragement or discouragement will have to be given early on, as the threshold is being approached or crossed that marks the onset of suppletion, of both the lexemecombining or phonologically-differentiating kind. This is hardly a matter for maintaining or losing suppletion.

Here is a bare list of such potentially relevant factors that have variously been suggested in the literature; expectations for suppletion to strike are supposed to be higher to the left of the greater-than symbol, and an asterisk marks patterns (often prematurely) assumed not to occur:

MORPHOLOGICAL TYPE:

flexive (a.k.a. fusional) $>$ agglutinative

KIND OF MORPHOLOGY:

derivation $>$ inflection $(>$ (word $>$ phrase) cliticisation $)$

WORD CLASSES AND SUBCLASSES:

closed $>$ open classes: $\quad$ auxiliaries $>$ full verbs 


$$
\text { pronouns }>\text { nouns }
$$

verbs $>$ nouns

verbs: $\quad$ BE $>$ HAVE $>$ DO $>$ motion/posture $>$ SEE, GIVE/SAY, HOLD, $\ldots$

nouns: $\quad$ persons $>$ animals $>$ things $>$ abstract

adjectives: $\quad$ GOOD/BAD $>$ LARGE/SMALL $>$ OLD/NEW $>\ldots$

numerals: $\quad$ ONE $>$ TWO $>$ higher, with: round $>$ unround

DERIVATIONAL CATEGORIES:

verbs: $\quad$ Aktionsart/verbal number $>$ causative $>\ldots$

nouns: $\quad$ motion $($ gender-switch) $>$ provenance $($ town $>$ country) $>\ldots$

numerals: $\quad$ ordinal $>$ distributive $>$ multiplicative $>$ absolute-counting

INFLECTIONAL CATEGORIES:

verbs: $\quad$ aspect $>$ tense $>\operatorname{mood}>$ polarity $>$ number $_{\text {agree }}>$ person $_{\text {agree }}$

$>(*)$ diathesis

nouns: $\quad$ number $>\left({ }^{?}\right)$ case $>(*)$ possessor $>\left({ }^{*}\right)$ state $>\left({ }^{*}\right)$ definiteness

adjectives/adverbs: comparison $>\ldots>$ agreement $/(*)$ gender $_{\text {agree }}$

general: inherent $>$ contextually assigned categories

semantic $>$ morphosyntactic categories

DISTRIBUTIONS OF SUPPLETIVE STEMS OVER TERMS OF INFLECTIONAL CATEGORIES:

unmarked vs. marked terms

(e.g., NOM vs. other cases; 3SG vs. other persons and numbers; SG vs. PL/DU)

paradigmatically 'closer' vs. more 'distant' terms:

(e.g., direct vs. oblique cases; 1st/2nd persons (speech-act participants) vs.

3rd person; POSITIVE vs. COMPARATIVE/SUPERLATIVE in adjective gradation) 
These suggested preferences are speculative, proposed on impressionistic evidence and often without convincing rationale; some have been shown to be dubious or wrong. Nonetheless, unless we are satisfied that (near-)synonyms for Nahbereich concepts being the best candidates to become suppletive and high-frequency lexemes being the likeliest to remain suppletive are just about the only worthwhile generalisations about suppletion, embraced already by Osthoff (1899/1900), any such hypothetical preferences deserve deeper probing.

Let us therefore look at some of these suggestions in a little more detail. As we have already mentioned, there has been some discussion in the literature over whether the concept of suppletion applies only in the domain of inflection or spills over into derivational morphology. Thus, in his contribution here, Hill, while restricting his discussion to inflection, does allow for it to appear within derivational groups as in his example (1b) where the Russian male animal words lis 'fox', lev 'lion', volk 'wolf' have corresponding female forms lisíca, l'víca, volčica beside the pair pës 'male dog' and súka 'female dog'. Such lexical pairings in turn bring us quite close to the pairings based on number rather than gender that are François's concern.

Within inflection the mode of morphological expression is often mentioned as making a difference, in particular whether it is flexive/fusional or agglutinative, i.e., whether exponents cumulative, variant, tightly-bound (etc.) or separative, invariant, loose (etc.). Predominantly fusional languages and fusional inflectional categories and paradigms are by far the most numerous on the suppletive record, although instances of agglutinative suppletion have been adduced, too (Corbett 2007: §3.1, among others). Derivational morphology is rarely fusional, which seems at odds with the belief that it inclines towards suppletion more than inflection does; but then, it has also been contested that what looks like suppletion in derivation (German Sohn - Tochter, vis- à- 
vis Enkel-Enkel-in, see above) indeed is genuine suppletion. Another kind of relation is that between a periphrasis and an inflected form as discussed for example in Vincent \& Börjars (1996), and as exemplified in already cited pairs such as Latin fecit '(s)he did' vs. factum est 'it was done'. The latter is sometimes called 'suppletive periphrasis' to distinguish it from other 'categorial' periphrastic formations (Haspelmath 2000, Corbett 2013, Cruschina 2013).

Available evidence does suggest that suppletion works in terms of a scale of asymmetric constraints which govern the environments which are conducive to its development so that flexive/fusional morphology is preferred to agglutinative, inherently determined inflection rather than contextual, semantically determined inflectional categories rather than morphosyntactic ones and so forth. Among other dimensions that are surely relevant are word class categories and subcategories, with pronouns in all probability being the most common class to exhibit the effect, followed by verbs and to a lesser extent nouns. These particular word class and subclass asymmetries, superimposed on the general division of the lexicon in its entirety into cognitively salient, Nahbereich vocabulary and other vocabulary, is adventitiously reflected in this collection, insofar as most attention turns out to be paid to verbal suppletion; pronouns, on the other hand, are getting short shrift despite being suppletive hotspots. But then, there are questions about pronoun alternants such as English $I-m e$, we - us being genuine instances of suppletion, rather than of the absence of genuine inflectional paradigms (as discussed, e.g., in Corbett 2005) - which is an issue in a sense analogous to verbal number alternants being mere 'lexical pairs' or real suppletion (Mithun 1988, François in this issue). In the case of adjectives, while suppletion for comparatives and superlatives is common (Bobaljik 2012), Osthoff (1899) thought suppletion for adjectival number and agreement was not attested, a 
belief echoed by Mel'čuk (1994) specifically for gender agreement. The recent literature has shown this conclusion to be premature (Börjars \& Vincent 2011, Nurmio 2017; not strictly an adjective, but Greek cardinal numeral 'one' suppletes for gender, énas/éna MASC/NEUT - mía FEM, the stem alternation emerging through phonological differentiation ${ }^{14}$ ), but nonetheless adjectival suppletion for number and agreement is less common than the nominal variety.

Even so questions remain. Why is the apparent categorial preference for suppletion arranged in this way? Can we for example detect here principles that link the semantic basis of grammatical categories to the semantic subclasses of predicates?

\section{THEORETICAL CHALLENGES}

Much of the descriptive literature on suppletion, whether synchronic or diachronic, takes for granted the concept of a paradigm, and for obvious reasons. Suppletion cannot be evidenced by single forms but only by sets of forms and a natural way to present such data is as paradigmatic tables. However, the question arises as to whether this way of proceeding is simply a matter of practical convenience or has a deeper theoretical motivation. The question is not a new one (Plank 1991), but it has come to have renewed relevance in the context of recent debates. Thus, Stump (2016) dedicates a chapter to the topic of 'Suppletion and heteroclisis' and concludes: 'the phenomenon of suppletion (which properly includes the phenomenon of heteroclisis) provides strong motivation for the paradigm-linkage hypothesis' (Stump 2016: 196), a hypothesis which in turn rests on the concept of paradigm as a theoretical construct. By contrast,

${ }^{14} \mathrm{IE} *$ sem, MASC *sem-s $>$ hens $>\ldots$, NEUT *sem $>$ hen, FEM *sm-iH ${ }_{2}>m(h) i a$. 
Jonathan Bobaljik, a leading exponent of Distributed Morphology (DM), has claimed that 'DM, with Impoverishment rules, can account for the appearance of paradigm structure, without positing that that structure is itself a part of linguistic knowledge' (2002: 67), and he concludes another case study with the assertion that within DM reference to a word's paradigm 'is neither needed nor possible' (Bobaljik 2008: 54). At the same time, he is a strong advocate of the data yielded by suppletion as a source of theoretical insight rather than a morphological dumping ground (Bobaljik 2012, 2015). In particular, suppletion is argued to provide evidence for two central claims of DM, namely hierarchical structure and locality, both in turn based on the notion of the morpheme as a minimal unit of linguistic organization.

A key principle then which informs Distributed Morphology (DM) is that the mechanisms which govern morphology are the same as those that apply in the domain of syntax within the Chomskyan/Minimalist framework. In particular, what this means is that the representation of morphological structure is a hierarchical configuration of heads, in more recent work obeying the one-feature on-head $(\mathrm{OFOH})$ principle (Baunaz \& Lander 2018), together with binary branching. Taken for granted too is the possibility of movement within these structures, so that word formation is derivational just as, on this view, syntax is. Functional heads may be inserted if the analysis requires it but crucially they do not have to be phonologically realised. At the same time there is a sister operation, Impoverishment, which permits the deletion of elements in appropriate circumstances. What, however, not possible within such a framework is for one derivation to refer to another derivation. Paradigm-based constraints by contrast require precisely such transderivational comparisons of outputs, although since in the Paradigm-Function framework they are generally stated within a non-derivational formalism the outputs are all there is. In other words, there is a kind of theoretical stand- 
off: (silent) heads, impoverishment and movement on the one hand vs. surface forms plus transderivationality on the other.

The nearest that we come to anything transderivational in DM is the mechanism of blocking, whereby an item with more specific properties takes precedence over a more general form, a variant of the Elsewhere Principle (Arregi \& Nevins 2013). Thus, for example, the existence of the form went blocks the operation of the mechanism that would otherwise generate *goed from the phonologically unspecified structure [PAST $\left[\sqrt{G O}_{\mathrm{GO}}\right]$. This blocking mechanism is deployed in the present volume by Remberger \& Pomino in their exploration of the rich range of suppletive patterns to be seen in 'go' verbs in Romance. By contrast, Kayne's contribution, while sharing many of the conceptual foundations of the DM approach, explicitly challenges the blocking approach and provides an independent account for the absence of the form * goed in English. The analytical price is paid instead in terms of additional - and sometimes silent - morphological material in the form of a class of theme vowels reminiscent of those to be observed in the conjugations of Romance verbs. We leave the reader - and do read on! - to decide which of these various mechanisms provides the best value for money!

Frans Plank

Somerville College

University of Oxford

$O X 26 H D(U K)$

Email:frans.plank@ling-phil.ox.ac.uk 
Nigel Vincent

Linguistics and English Language

The University of Manchester

M13 9PL (UK)

Email:nigel.vincent@manchester.ac.uk 


\section{References}

ArRegi, KARLOS \& ANDREW NeVINS, 2013. 'Contextual neutralization and the Elsewhere Principle', in Ora Matushansky \& Alec Marantz (eds.), Distributed Morphology Today: Morphemes for Morris Halle, Cambridge, MA: MIT Press, $199-221$.

BAUNAZ, LENA \& ERIC LANDER, 2018. 'Nanosyntax: The basics', in Lena Baunaz, Karen De Clercq, Liliane Haegeman \& Eric Lander (eds.), Exploring Nanosyntax, Oxford \& New York: Oxford University Press, 3-56.

Baerman, Matthew, Greville G. Corbett, \& Dunstan Brown, (eds.) 2010. Defective Paradigms: Missing Forms and what they Tell us, Oxford: Oxford University Press and British Academy.

BITTNER, ANDREAS, 1988. 'Reguläre Irregularitäten', STUF - Language Typology and Universals 41, 416-425.

BOBALJIK JONATHAN, 2002. 'Syncretism without paradigms: Remarks on Williams 1981, 1994', in Geert Booij \& Jaap van Marle (eds.), Yearbook of Morphology 2001, Dordrecht: Springer, 53-85.

BobalJiK Jonathan, 2008. 'Paradigms, optimal and otherwise: A case for skepticism', in Asaf Bachrach \& Andrew Ira Nevins (eds) Inflectional Identity, Oxford: Oxford University Press, 29-54.

BobalJik, Jonathan, 2012. Universals in Comparative Morphology: Suppletion, Superlatives and the Structure of Words. Cambridge, MA: MIT Press.

BoBALJIK, JonAthan, 2015. 'Suppletion: Some theoretical implications', Annual Review of Linguistics 1, 1-18.

BÖRJARS, KERSTI \& Nigel VinCENT, 2011. 'The pre-conditions for suppletion', in 
Alexandra Galani, Glyn Hicks, \& George Tsoulas (eds.), Morphology and its interfaces, Amsterdam: John Benjamins, 239-265.

BUTT, MiRIAM \& ADITI LAHIRI, 2013. 'Diachronic pertinacity of light verbs', Lingua $135,7-29$.

BYBee, JoAn, 2007. Frequency of Use and the Organization of Language. Oxford: Oxford University Press. (Reprinting 'Regular morphology and the lexicon', Language and Cognitive Processes 10, 425-455, 1995.)

Corbett, GReviLle G., 2005. 'Suppletion in personal pronouns: Theory versus practice, and the place of reproducibility in typology', Linguistic Typology 9, 123.

Corbett, Greville G., 2007. 'Canonical typology, suppletion and possible words', Language 83, 8-42.

Corbett, Greville G., 2013. 'Periphrasis and possible lexemes', in Marina Chumakina \& Greville G. Corbett (eds.), Periphrasis: The Role of Syntax and Morphology in Paradigms. Oxford: Oxford University Press, 169-189.

CRuschina, SiLvio, 2013. 'Beyond the stem and inflectional morphology: An irregular pattern at the level of periphrasis', in Silvio Cruschina, Martin Maiden, \& John Charles Smith (eds.), The Boundaries of Pure Morphology: Diachronic and Synchronic Perspectives, Oxford: Oxford University Press, 262-283.

Gabelentz, GeOrg VON Der, 1891. Die Sprachwissenschaft, ihre Aufgaben, Methoden und bisherigen Ergebnisse. Leipzig: T. O. Weigel Nachfolger.

GRASSERIE, RAOUL DE LA, 1895. 'Du syncrétisme pronominal', Revue de Linguistique et de Philologie comparée 28, 47-72, 113-157.

Haspelmath, Martin, 2000. 'Periphrasis', in Geert Booij, Christian Lehmann, \& Joachim Mugdan (eds.), Morphology: A Handbook of Inflection and Word 
Formation, Berlin: Walter de Gruyter, 654-664.

HiLl, Eugen, 2015. 'Suppletion replication in grammaticalisation and its triggering factors', Language Dynamics and Change 5, 52-91.

JANDA, LAURA A. \& Francis M. TYers, 2019. 'Less is more: Why all paradigms are defective, and why that is a good thing', Corpus Linguistics and Linguistic Theory $15,000-000$.

JOFFre, MARIE-DOMINIQUE, 1986. 'La signification temporelle et aspectuelle de l'adjectif en -*to', Revue des Études Latines 64, 211-222.

KIBRIK, ALEKSANDR E., 1977. Opyt strukturnogo Arčinskogo jazyka, vol. 2:

Taksonomičeskaja grammatika. Moscow: Izd'vo Moskovskogo Universiteta.

Lieberman, Erez, Jean-Baptiste Michel, Joe Jackson, Tina Tang, \& Martin A.

NowAK, 2007. 'Quantifying the evolutionary dynamics of language', Nature 449, 713-716.

MAIDEN, MARTin, 2004. 'When lexemes become allomorphs: On the genesis of suppletion', Folia Linguistica 38, 227-256.

MaIden, Martin, 2018. The Romance Verb: Morphomic Structure and Diachrony. Oxford: Oxford University Press.

Meid, Wolfgang, 1976. 'Zur Etymologie des Wortes für “Mensch” im Irischen', in Anna Morpurgo Davies \& Wolfgang Meid (eds.), Studies in Greek, Italic, and Indo-European Linguistics Offered to Leonard R. Palmer on the Occasion of his Seventieth Birthday, Innsbruck: Institut für Sprachwissenschaft der Universität Innsbruck, 173-179.

MEL'ČUK, IGOR, 1994. 'Suppletion: Toward a logical analysis of the concept', Studies in Language 18, 339-410.

Mithun, MARIANNE, 1988. 'Lexical categories and the evolution of number marking', 
in Michael Hammond \& Michael Noonan (eds.), Theoretical Morphology: Approaches in Modern Linguistics, San Diego: Academic Press, 211-234.

NuRMIO, SiLVA, 2017. 'The development and typology of number suppletion in adjectives', Diachronica 34, 127-174.

Osthoff, Hermann, 1899. Vom Suppletivwesen der indogermanischen Sprachen: Akademische Rede zur Feier des Geburtsfestes des höchstseligen Grossherzogs Karl Friedrich am 22. November 1899 bei dem Vortrag des Jahresberichts und der Verkündigung der akademischen Preise gehalten. Heidelberg: Universitätsbuchdruckerei von J. Hörning. (Erweiterte akademische Rede. Heidelberg: Kommissionsverlag von Alfred Wolf, 1900.)

Petré, Peter, 2012. 'On the distribution and merger of is and bið in Old and Middle English', Transactions of the Philological Society 111, 301-325.

Plank, Frans, 1991. 'Rasmus Rask's dilemma', in Frans Plank (ed.), Paradigms: The Economy of Inflection, Berlin: Mouton de Gruyter, 161-196.

Plank, Frans, 2016a. 'Vom Suppletiv(un)wesen, in Beziehung zu Paradigmenstruktur und in besonderer Rücksicht der historischen Natur beschränkter Möglichkeiten', in Andreas Bittner \& Klaus-Michael Köpcke (eds.), Regularität und Irregularität in Phonologie und Morphologie: Diachron, kontrastiv, typologisch, Berlin:

Walter de Gruyter, 1-28.

Plank, Frans, 2016b. 'Review article of Bobaljik 2012', Linguistic Typology 20, 687713.

PLANK, FRANS, 2013. 'Re-distributions of suppletive stems over inflectional paradigms', unpublished, available at http://ling.unikonstanz.de/pages/home/plank/for_download/unpublished/24_FP_ReDistribution SuppletiveStemsUpperGermanDialects.pdf 
Stump, Gregory, 2016. Inflectional Paradigms: Content and Form at the SyntaxMorphology Interface. Cambridge: Cambridge University Press.

VinCENT, Nigel \& Kersti BöRJARS, 1996. 'Suppletion and syntactic theory', in Miriam Butt \& Tracy Holloway King (eds.), Proceedings of the LFG Conference 1996, available at:

http://web.stanford.edu/group/cslipublications/cslipublications/LFG/LFG1-1996/

WERNER, OTMAR, 1977. 'Suppletivwesen durch Lautwandel', in Gaberell Drachman (ed.), Akten der 2. Salzburger Frühlingstagung für Linguistik, Tübingen: Narr, $269-283$.

WiLli, ANDrEas, 2016. 'The Oscan perfect in -TT-', Transactions of the Philological Society 114, 75-94.

Wurzel, Wolfgang Ulrich, 1985. 'Zur Suppletion bei den Dimensionsadjektiven', Linguistische Studien, Reihe A: Arbeitsberichte 126, 114-143. Berlin:

Zentralinstitut für Sprachwissenschaft, Akademie der Wissenschaften der DDR.

Wurzel, Wolfgang Ullrich, 1987. 'Zur Morphologie der Dimensionsadjektive', in Manfred Bierwisch \& Ewald Lang (eds.), Grammatische und konzeptuelle Aspekte von Dimensionsadjektiven (Studia Grammatica 26+27), Berlin: Akademie-Verlag, 459-516. 